\title{
Development of Creative Industries as Regional Leaders in National Tourism Efforts Based on Geographical Indications
}

\author{
Rian Saputra \\ Faculty of Law, Universitas Sebelas Maret, Surakarta, Indonesia \\ Email Coresponden: rians7o1o@gmail.com
}

\begin{abstract}
This study aims to examine and explain the role of various parties both government, business and community in synergy to develop Geographical Indications products as creative economic potential to develop national tourism based on regional superior products and Geographical Indications. This research is writing normative law using the legislative approach method. The results of the study show that the growth of the creative industry as a superior product based on geographical indications in Indonesia is quite rapid. Creative Industries as regional superior products based on geographical indications can be used and developed as a tool to attract tourists to visit Indonesia due to their unique characteristics or characteristics, and vice versa tourism has been made a partner by the Directorate General of Intellectual Property to promote Indications products Geographically owned by Indonesia at the global level or in every international tourism event.
\end{abstract}

Keywords: Creative Industries, Geographical Indications, Tourism

\begin{abstract}
Abstrak
Penelitian ini bertujuan untuk mengkaji dan menjelaskan peran berbagai pihak baik pemerintah, dunia usaha dan masyarakat dalam bersinergi untuk mengembangkan produk Indikasi Geografis sebagai potensi ekonomi kreatif untuk membangun kepariwisataan nasional yang berbasis produk unggulan daerah dan Indikasi Geografis. Penelitian ini merupakan penulisan hukum normatif dengan metode pendekatan perundang-undangan. Hasil Penelitian menunjukkan bahwa pertumbuhan industri kreatif sebagai produk unggulan daerah berbasis indikasi geografis di Indonesia cukup pesat. Industri Kreatif sebagai produk unggulan daerah berbasis indikasi geografis dapat digunakan dan dikembangkan sebagai alat guna daya tarik wisatawan untuk datang berkunjung ke Indonesia dikarenakan kekhasan ataupun karatekristik uniknya, demikian sebaliknya pariwisata telah dijadikan patner oleh Direktorat Jenderal Kekayaan Intelektual guna mempromosikan produkproduk Indikasi Geografis yang dimiliki oleh Indonesia dalam tataran global atau dalam setiap event pariwisata internasional.
\end{abstract}

Kata Kunci: Industri Kreatif, Indikasi Geografis, Pariwisata . 


\section{Introduction}

Indonesian economy's wheels have so far relied too much on natural resources which are the richness of the country. With the growth of the tourism sector, creative industries are also developing which support the sector. Youth-driven creative economy and Micro , Small and Medium Enterprises ( MSMEs) are developing quite rapidly. Clearly this affects national economic development very strongly. As Mary Elka Pangestu has said, the creative economy contributes 7.6 percent of Gross Domestic Product (GDP) and 7.5 percent to the workforce at the national level. (Ganefi, 2019) Of the many forms of regional creative industries, one of them is an indication product Geography, for example, as a result of group creativity (factor) is: a. Carved Furniture in Jepara, b. The Spinning of Bali Gringsing, c. Mandar Weaving Silk, and $d$. Tanimbar Weaving at the Tie. Geographical indication is a part of the Intellectual Property developed by countries around the world since the last decade. IG is the mark used for products of a specific geographical origin and of a quality or reputation associated with their origin. In general, the IG consists of the product name followed by the name of the product area or place of origin. (Asfiyah siti, 2015)

Some IG products are not included in the category of Creative Industry, but are widely known as regional superior natural products. Indonesia is, as is well known, one of the countries with abundant natural resources. The abundance of these natural resources fosters a variety of unique biological as well as crop, thereby supplying a variety of potential natural gifts that are exceptional such that the potential gives rise to a variety of farming, planting, production, handicraft and forestry products that define the geographical location where the potential is located. Cilembu Sweet Potato, Gayo Coffee, Bali Kintamani Coffee, Lampung Black Pepper, Muntok White Pepper, Toraja Coffee, Malang Stone Apples, Malang Stone Ceramics, Dinoyo Ceramics, Kasongan Pottery and others. The natural potential is a blessing for economic development for the indonesian people, it is unfortunate if there is no legal security for the diverse natural potential of each region in Indonesia. If properly controlled, abundant natural resources can support the country as a feature of a market and can be used as a trade commodity, which in turn is supposed to boost the economy of the area from which the product originates. (Apriansiya., 2020)

The history of geographical indication recognition was first governed in the 1883 Paris Convention, which introduced security measures on the boundaries of measures and prevention of unfair competition. This is also governed by the False Indication and Border of Measures Agreement of 1891 in Madrid. In addition, the Lisbon Treaty provides for the security of the 1958 origin indication regulating the international registration of the origin indication. In the 1994 General 
Agreement on Tariffs and Trade Rounds (GATT), IG in the Trade Related Aspects of Intellectual Property Rights (TRIPs) was signed. (Rian Saputra, 2019 et.all)

The Geographical Indications Regulation in Indonesia is currently regulated in Republic of Indonesia Law No. 20 Year 2016 About Geographical Marks and Indications (hereinafter referred to as Law No. 20/2016); In the Law , the concept of Geographical Indication is: "a sign indicating the region of origin of goods and/or products due to geographical factors including natural factors, human factors or the combination of those two factors that offer the goods and/or products created a certain reputation, price, and characteristics." Among the many items of geographical indications registered at the DirectorateGeneral for Intellectual Property (DJKI) (Rian Saputra, 2019), one of which is the jepara carving art which is recognized as a creative industry typical of local wisdom. (marketeers.com., 2020) Then there is the gringsing weaving which is one of the products of the Cultural Industry and Fashion Industry Geographical Indications coming from Bali Province. (I Lodra Nyoman, 2016).

Then Kintamani Coffee's Geographical Indication Product as a superior product in the Bali region was classified as an IG product with registration number IDIG ooooooool (December 5, 2008). The three types of Geographical Indications products already have a good reputation in the world of trade, therefore if they are developed to improve the national economy through tourism instruments, there is a considerable chance. The presence of superior goods and innovative industries in a area is certainly very important for regional economic development, especially in the context of improving local community welfare. Where a product is the more special and distinctive it is, the more desirable it is so, the expected customers will be found. At the end, this is supposed to increase the value of the sale and added value for the company. (Apriasnya Nizare, 2018)

For example, after being designated as a Regional Leading Product, namely Geographical Indications, IG Kintamani Bali coffee products have increased demand and market expansion, there are additional processing/ labor groups from 40 groups to 60 groups, for staff from 1,750 people to 2,640. (Apriansya Nizar, 2018) According to the Republic of Indonesia's Ministry of Trade, the creative economy (ekraf) has significant potential to be developed, and can be a pillar of the national economy. Creative economy is an industry that creates a range of goods related to the process of embodying an idea or ideas into intellectual property, which has a strong economic benefit for people's welfare and jobs and can improve a country's economic development. (Republic of Indonesia trade department, 2015)

While Bekraf (Creative Industry Agency) aims to contribute to the creative economy by hitting $\mathrm{Rp} 1,041$ trillion in 2018 , and the creative 
sector is projected to absorb 18.2 percent of the workforce and contribute US\$23.7 billion to national exports. Although it is expected to be estimated at Rp 1,123 trillion of GDP in 2019 and contributes US \$25.1 billion in exports. According to Triawan Munaf (Head of Bekraf), innovative ideas should never run out so that natural resources (SDA) are needed to replace them as the backbone of the national economy. (Metta Dharmasaputra and Desy Setyowati, 2018) Collaboration between all stakeholders, including the business sector, government and society is required in an attempt to accomplish this. The issue addressed in this paper is how the position of different parties in synergizing with creative economic actors should be to help tourism growth in Indonesia. Therefore this paper aims to explore and clarify the role of various parties in collaboration, both government, business community and society, to produce products of Geographical Indications as innovative economic potential.

\section{Research Methods}

The approach employed is normative (doctrinal) rule, based on the subject of this paper. Although focused on nature and intent, this paper uses descriptive legal research (descriptive legal research), since in this paper the author must describe the circumstances and problems associated with "Creative Industries as Regional Leading Products in Efforts to Build National Tourism Based on Geographical Indications" in order to realize customer empowerment, describe preliminary data related to the current problem and then search for theories or hypotheses to solve existing problems In this paper two types of approach methods are used, namely the main approach method and the method of supporting approach. The key forms of approach are: the formal approach, the comparative approach and the case approach. Although the strategy used by the supporters is the legal sociology approach, since this technique would examine how the responses and experiences arise as the group culture functions. Both materials obtained and collected will be analyzed using qualitative analysis by defining or comparing existing hypotheses with material obtained from interviews, data and literature studies from various sources, followed by data coding and editing, then interpreting to give meaning to the meaning study, explaining trends or categories seeking relationships between different coworkers. (I Gusti Ayu Ketut Rachmi Handayani, Lego Karjoko, Abdul Kadir Jaelani, 2019)

\section{Discussion}

\section{Tourism as a Creative Industry}

Indonesia tourism is a rapidly growing industry. In addition to natural resources, Indonesia also has strong potential for tourism, from which both economic, historical and human resources aspects can be created. According to the Minister of Tourism based on the version of The World Travel \& Tourism Council (WTTC), Indonesia is the world 's number nine (9) nation with the 
fastest growth in tourism. Tourism growth in Indonesia reached 22 per cent above the world tourism average growth of 6.4 per cent in 2017 and ASEAN 7 per cent. Indonesia is much higher than Malaysia at 4 percent, Singapore at 5.8 percent and Thailand at 8.7 percent compared with other Asean countries. Tourism is also one of the main foreign exchange earning markets, adding to national revenue following oil palm (CPO), oil and gas , and coal mining. (Tulus Wijanarko, 2018) Law No. 9 of 1990 on Tourism, Article 1(3) that Tourism is all tourism-related, including the mining of tourist items and attractions, as well as field-related businesses. Going according to the Major Indonesian dictionary means going on a picnic or together. Meanwhile, Article 1(1) of the Law on Tourism allows for a travel operation or part of the activity that is carried out voluntarily and is temporary in order to experience tourist items and sights. A tourism business is likewise an operation aimed at providing tourism services, providing or selling tourist items and attractions, tourism facilities businesses, and other related businesses in the sector (number 5 ).

According to Caretourism, the tourism sector is a collection of production units in various industries that provide the specifically needed goods and services for visitors. The tourism sector as an economic activity has become a potential pillar and development priority for a number of countries, particularly for developing countries such as Indonesia which have vast regional potential with considerable tourist attractions, many natural beauties, diverse cultural heritage, and (ethnic) community life. (Alfiah Mudrikah, et.all, 2014) Tourism activities are activities related to attempts to fulfill people's desires for enjoyment in life. The enjoyment is enjoyed thanks to the services other parties offer. Tourism is a market itself. According to the word, industry understanding according to U.S. Hornby (1978: 22) is the consistency of hard work, products production, wealth formation by human efforts. In order to survive, manufacturing operations involve hard work, which will produce a variety of goods that will provide consumer happiness and health. That is why the word industry often means an company manufacturing a commodity. The commodity is a collection of services that have physical, psychological , and social aspects. (Hakim Lukman, 2010)

It can be inferred from different literatures and from some of the items found in the law that tourism is more of a commercial operation in the service sector. In addition to being a tourist destination, different factors are required to promote tourism activities, in order to establish a position as a tourist destination involves imagination from human ideas. Thus tourism businesses generally produce creative human resources products. Indonesia also has a significant number of human capital, in addition to its abundant natural resources. Developing human resource talent in the tourism industry would generate tourism products which have high economic value in the national economy is very significant. (Ganefi, 2018) According to Oemar Hamalik, tourism products are manufactured by various companies such as hotel services, transport services, entertainment services, tour-organization services, etc. Provided by the community including the people's streets and hospitality. Nature offers such as natural scenery, beaches, oceans etc. The facilities are a set of interrelated 
modules, called "Box" (Oemar Hamalik, 1978) M.J. Projogo (1973: 22) notes that the tourism industry is a process of tourism economic operation whose goods are services to meet the needs of tourists in a comparable (pleasant), privacy (at home because they are not disturbed) and protection (personal security guaranteed) so that tourists feel welcome. (Hamalik Oemar, 1978)

The tourism industry is closely linked with the creative industries, especially with regard to the superior regional products. The two industries must go hand in hand and complement each other, as Minister of Law and Human Rights Yasonna Hamonangan Laoly conveyed, geographical indications, besides having the potential to build economic power for remote areas in Indonesia, contribute to job creation as well as to household income, increase the income of farmers and producers, as well as the recognition of IG as a region This was produced by producers of Malang Apple Stone through agrotourism, which is very common among visitors and tourists. (Widya Lestari, 2016) Furthermore, the Ministry of Tourism has become a partner of the Directorate-General for Intellectual Property (DJKI) to promote products of Geographical Indications owned by Indonesia at a global level or at any international event. (Fajar Sulaeman Taman, 2019) According to data from the Ministry of Tourism and Creative Economy of the Republic of Indonesia (2011), 3 creative industry sub-sectors strongly related to the tourism industry and significantly contributing to the development of national tourism are culinary $32 \%$, fashion $28.7 \%$ and then art $14.7 \%$, but the growth of all three continues to be in and out. 19.5 million an annual worker. (Diana, et.all., 2017)

\section{Geographical Indications as Part of Intellectual Property}

In accordance with the times, the protection of the rights possessed by every human being requires an arrangement, including the case with IPR. Respect and appreciation for KI is now a necessity, including respect, respect and protection of rights which are communally owned or known as the concept of protecting geographical indications. (Djulaeka, 2014) The existence of geographical indications has been recognized as part of IC since the signing of the TRIPs Agreement in 1994. TRIPs are considered an important milestone in efforts to liberalize international trade, therefore protecting geographical indications has become one of the central topics to be accommodated in the provisions of TRIPs. Even in the WTO forum, especially in the standing committee meeting agenda on the law of trademarks, industrial designs, and geographical indications, the issue of protecting geographical indications became a routine agenda in every meeting in international forums until 2003. (Djulaeka, 2014)

Indeed, if observed, protection against geographical indications has actually been arranged before the TRIPs, where geographical indications are known in several conventions or treaty even though it does not clearly mention the term geographical indications, for example in the Paris Convention for the Protection of Industrial Property in 1983, Madrid Agreement Concerning the Reputation of Flase Indication of Origin which was revised in 1979. (Djulaeka, 
2014) as well as in the Lisbon Agreement which has been revised as the Geneva Act of the Lisbon Agrrement on the Appellation of Origin and Geographical Indication, adopted at the Diplomatic Conference in May 2015. (Nurul Barizah., 2016) In the Paris Convention for example, acknowledgment of an indication of source or appellation of origin is not clearly explained. Article 1 (2) of the Paris Convention only states that "the protection of industrial property has as its object patents, utility models, industrial designs, trademarks, service marks, trade names, indications of source or application of origin, and the repression of unfair competition". (Djulaeka, 2014) simply means that protection of industrial property rights is part of the patent object which includes, among others, utility models, industrial designs, trademarks, service marks, trade names, indications of source or title / title of origin, and restraints unfair competition.

Basically, the Paris Convention regulates the concept of geographical indications as indications of source or application of origin, but does not provide a clear definition in this regard. In this Convention only provides protection against indicative origin products that may not enter a country if the product is not really from the country concerned. The Paris Convention does not provide a clear description regarding specific arrangements regarding the quality or characteristics of the product from which the source of the indication is used. Although the Paris Convention still has many shortcomings, the arrangement has become the first step towards the recognition of the concept of geographical indication internationally. (Indra Rahmatullah., 2014) The second international agreement is the Madrid Agreement. The Madrid Agreement has provided broader protection regarding the indication of source. Article 1 of the Madrid Agreement states: "all goods bearing a false or deceptive indication by which one of the countries to which this agreement applies, or a place situated there in, is directly or indirectly indicated as being the country or the place of origin shall be seized on importation into any of the said countries". (Djulaeka., 2014)

Interpreted as providing protection against misleading information related to the goods originated. But unfortunately the Madrid Agreement does not specifically regulate the concept of Geographical Indications. This agreement only stipulates the obligation to confiscate any items of geographical indication that are false or misleading. So that in principle, the Madrid Agreement is a multilateral agreement that specifically regulates actions that lead to wrong use related to the source or origin of the goods. This agreement does not increase the level or information regarding the protection of indications of origin as stipulated in the Paris Convention. With the Madrid Agreement, member countries are prohibited from providing exceptions to wine products except for other products, as stipulated in the provisions of Article 4 of the Madrid Agreement, which states that: "the courts of each country shall decide what applications, on account of their generic characters, do not fall within the terms of this agreement, regional applications concerning the source of products of the vine being, however, excluded from the reservation specified by this article ". (Djulaeka, 2014) 
Simply stated, this provision has given the potential for differences in approaches between member countries to the problem of false indication of source, especially for wine products. Indonesia's position itself has now ratified the Madrid Agreement, through Presidential Regulation No. 92 of 2017 concerning ratification of the protocol relating to the Madrid agreement concerning the international registration of mark, 1989 (the protocol related to Madrid's agreement on international trademark registration, 1989). The third agreement is the Lisbon Agreement (Lisbon Agreement). The Lisbon Treaty was made in 1958 and was amended in Stockholm in 1967. This agreement aims to respond to the needs of international law and facilitate protection of geographical indications such as appellation of origin in several countries other than the country of origin of such geographical indications through a single registration system at the International Bureau WIPO. The existence of the Lisbon Treaty will help establish a directed international registration system, because the protection of geographical indications in several countries is basically complicated because there are still different legal concepts that already exist in several countries (including differences in national legal traditions) in a framework both historically and in the country's economic conditions. (Djulaeka, 2014)

This means that the existence of reputation as the main criterion is strongly influenced by the long history that has been built on a product, including the results of consumer surveys or the role of business actors in the area of origin of a product. From these provisions, Trias Palupi distinguishes 3 (three elements) contained in the concept of geographical indications with the concepts in other agreements, namely: (Trias Palupi Kurniangrum., 2016) Similar to the Paris Convention and Madrid Agreement, the regulation of appleation of origin provides protection against fraudulent or unhealthy competition and consumer protection against the origin of goods or products produced by a particular region of the country incorporated in the Lisbon Agreement. This is clarified in article 3 of the Lisbon Agreement, which states that: "protection shall be ensured against any usurpation or imitation, even if the true origin of the product is indicated or if the appleation is used in translated form or accompanied by terms such as" kind "," Type "," make "," imitation ", or the like"

The provisions of the appellation of origin contained in the Lisbon Agreement are closer to the formulation of the protection of geographical indications, compared to the arrangements contained in the Paris Convention and Madrid Agreement. Indonesia itself has not ratified the Lisbon Agreement. If examined several benefits for Indonesia when ratifying the agreement, including: (Trias Palupi Kurniingrum., 2016) While the regulation of geographical indications themselves in Indonesia, officially began to be known since the Trademark Law was enacted. The operation was only implemented in 2008 with the issuance of Government Regulation No. 51 of 2007 concerning Geographical Indications. Then updated with Law Number 20 Year 2016 Regarding Trademark and Geographical Indications. According to article 53 Paragraph (1) of Law No. 20 of 2016, Geographical Indications obtain protection 
after registration by the minister for a period of protection during the preservation of reputation, quality, and characteristics which form the basis of the deviation of such Geographical Indications protection. So if the characteristics and quality of a geographical indication are gone, the protection will be lost. While in the TRIPs, the regulation of geographical indications is contained in article 22 paragraph (1) of the TRIPs.

Therefore, the definition of a geographical indication based on the TRIPs agreement is a sign that identifies a territory of a member country, or region or region within the territory as the origin of the goods, where the reputation, quality and characteristics of the goods concerned are largely determined by the geographical factor. Based on these provisions, it can be understood that the origin of goods and services attached to the reputation, characteristics and quality of goods related to a certain area must be protected legally. For example, the quality of Malang apples is attached to the region or geographical area, Malang. Likewise with Garut dodol, which is produced by people in the City of Garut. Therefore, in the TRIPs agreement, producers are prohibited from using labels or marks (or brands) for the goods they produce, which are not in accordance with geographical indications. For example include the label "Toraja coffee" or "Sidikalang coffee" for coffee that is not produced in Toraja or Sidikalang. This prohibition is then confirmed in article 22 paragraph (2) of the TRIPs.

Member countries are required to provide legal means for interested parties to prohibit the use of any means in marking goods that give instructions or a misleading impression to the public that the goods concerned originate from other regions than the actual origin of the goods. (Ok Saidin, 2004) These provisions are intended to prevent actions that can mislead consumers. Although geographical indications are regulated in the Trademark Law, geographical indications are not the same as brands. A geographical indication regulated in a TRIPs agreement cannot be owned by a person but rather functions as an identifier used by producers in one place. (Tomi Suryo Utomo., 2009) It is known that Indonesia is an archipelago country and has a lot of potential Geographical Indications and very diverse tourism. Indonesia has an area of 1,910,931.32 $\mathrm{km}^{2}$ and has around 17,00o islands stretching from Sabang to Merauke and has a population of $259,940,857$ inhabitants. Apart from that small islands stretching $6,400 \mathrm{~km}$ from west to east and around $3000 \mathrm{~km}$ from north and south and therefore naturally provide diversity (Training Proceedings and Workshops, Sustainable Tourism Planning, 1997). In addition to a vast area, Indonesia is supported by a very diverse source of tourism. Where tourism in Indonesia has various criteria for aspects of tourism. This diversity is supported by local natural, cultural / cultural, social and economic factors.

In Indonesia, the problem of tourism is the concern of everyone, especially people who really enjoy enjoying the beauty of nature, almost every region has beautiful tourist attractions and has its own uniqueness that is not owned by other regions. In addition there are many tourist attractions that are famous for reflecting the cultural characteristics of the region such as: regional food, art, 
batik, plant products, and others. Therefore, every tourist attraction must be maintained and cared for and needs to be preserved without exception. In connection with tourism, there needs to be an understanding of the perception of all parties in order to support tourism activities.

According to Article 1 number 4 of Law Number 10 Year 2009 concerning Tourism it is explained that Tourism is all multidimensional and multidisciplinary tourism-related activities that emerge as a manifestation of the needs of each person and country as well as interactions between tourists and the local community, fellow tourists, the Government, Local Government and entrepreneurs. This shows that tourism has a multidimensional and multidisciplinary nature. Tourism is an industry that covers various aspects ranging from transportation services, hospitality accommodation, natural scenery including mountain and beach nature, entertainment activities such as various arts, including in the recent development of culinary cultural tourism. The tourism activities are required to meet the needs and harmony with interactions between the government, tourism industry entrepreneurs, employees, tourists, as well as those who do not know the importance of the local community, which are oriented not only at present, but also future generations related to economic, social, environmental growth which is always seen from the needs of tourists, the tourism industry and the local community. (Ni Ketut Supasti Dharmawan., Et.all., 2017)

With the development of the creative industry that is experiencing an increasing trend from year to year, as released by the Head of the Creative Economy Agency. Triawan Munaf, that "In 2015, the contribution of the creative industry to GDP was recorded at 852 trillion. At that time the industry absorbed $13.9 \%$ of the workforce and contributed US $\$ 19.4$ billion to national exports. Furthermore, the contribution of the creative industries was recorded to increase to 922.6 trillion in 2016. This year Bekraf targets creative economy contributions to reach 1,041 trillion. Creative industries are expected to absorb $18.2 \%$ of the workforce and contribute US $\$ 23.7$ billion of national exports, while in 2019, the contribution is targeted to be Rp. 1,123 trillion of GDP and contributed US \$ 25.1 billion in exports ". (Desy Setyowati \& Metta Dharmasaputra, 2018) There are three sub-sectors of the creative industry that are closely related to the tourism industry and make a significant contribution to the development of national tourism, namely culinary $32 \%$, fashion $28.7 \%$ and then craft 14.7\%. (Princess Diana., Et.all, 2017)

The increase in the contribution of the creative industries which showed a significant increase from year to year, was apparently not accompanied by efforts to protect intellectual property rights (IPR), it can be seen from the many potential indications of geography, only 67 (sixty seven) were registered as Geographical Indication products and 4 (four) of them are Geographical Indications products belonging to foreign countries which are registered using international legal instruments. (Rian Saputra., 2020)

The low protection of Intellectual Property Rights in Indonesia, apparently has an impact on the many uniqueness such as the field of traditional cultural 
arts that have high artistic value stolen / claimed by other countries as stated as follows batik from Java by Adidas, Old Manuscripts from Riau by the Government of Malaysia, Manuscripts from West Sumatra by the Government of Malaysia, Manuscripts from South Sulawesi Government of Malaysia, Manuscripts from Southeast Sulawesi by the Government of Malaysia, Rendang from West Sumatra by unscrupulous Indonesian citizens of Malaysia, Sambal Bajak from Central Java by elements of the Dutch Citizens, Sambal Petai from Riau by a Dutch National Person, Sambal Pineapple from Riau by a Dutch National Person, Tempe from Java by several foreign companies, Rasa RasaSayange song from Maluku by the Malaysian Government, Reok Ponorogo Dance from East Java by the Malaysian Government. (Candra Irawan., 2011)

Claims / theft of traditional arts and culture in various regions as ancestral heritage as geographical indications is certainly very detrimental to the Indonesian nation, moreover the government is currently actively building the tourism sector which is expected to be one of the sources of state revenue besides opening business and employment opportunities, also as a source of foreign exchange, especially state revenues outside the tax sector for the sake of national development. Concern about the theft of traditional arts and culture from various regions in the country, especially by the state of Malaysia some time ago, if not immediately addressed wisely, it is not impossible that in the future hundreds or even thousands of Indonesia's original wealth will belong to other countries. According to professor Emeretus of the Faculty of Law at Padjadjaran University in Bandung, Eddy Damian, "Due to various weaknesses, Indonesian culture and art are often claimed by other countries, because the data is weak, Indonesia is powerless. Even if you have a list of intellectual property, including cultural arts, the list can be submitted to the World Intellectual Property Organization in Geneva to get international recognition. But that hasn't been done by Indonesia yet. (Eddy Damian., 2009)

This shows that the local government's indifference to the arts and culture in their area that causes the inventory of various cultural arts that have long been growing and developing in the midst of the community bequeathed to their children and grandchildren to be preserved and preserved, is claimed by other countries as their own. Even the country concerned was proclaimed as the nation's identity. For example, the Ponorogo reog dance was made an icon of Malaysia's tourism year with the slogan "Trully Of Asia". Whereas based on the authority as stipulated in the Tourism Act, the government should be able to make various publications on a massive scale in various countries, both through the mass media, books, and through tourism exhibition events.

\section{Conclusion}

The creative industry is experiencing very rapid progress, along with the advancement of the tourism industry that can be relied upon not only as opening up business opportunities, employment and as a source of state income even further, Leading Products and Geographical Indication-Based Creative Industries and tourism industries are assets a national that is always renewable along with 
the changes and progress of human civilization, therefore it is necessary to get protection by registering as intellectual property. Until now only 67 (sixty seven) of the many potential Geographical Indications that exist throughout Indonesia are registered with the DJKI. This is a number that sees a little amount of potential possessed by all regions in Indonesia, the number also shows that the local government's indifference to the arts and culture in their area that causes the inventory of various cultural arts that have long been growing and developing in the midst of a society that is ancestral inheritance to children and grandchildren to guard and preserve, it is claimed by other countries as their own. Even the country concerned is proclaimed as the nation's identity, therefore cooperation from all parties is needed to provide protection and make cultural heritage sustainable.

\section{References}

Candra Irawan. 2011. Politik Hukum Hak Kekayaan Intlektual Indonesia, Kritik Terhadap WTO//TRIPS, Agreement dan Upaya Membangun Hukum Kekayaan Intelektual Demi Kepentingan Nasional, Jakarta: Mandar Maju.

Chintami Dian Balenina, "Partisipasi Masyarakat dalam Pengelolaan Desa Sampah Mandiri di Desa Kalisoro, Tawangmangu, Kabupaten Karanganyar", Jurnal Bestuur, Volume 7, No. 1 (2019).

Djulaeka. 2014. Konsep Perlindungan Hak Kekayaan Intelektual: Prespektif Kajian Filosofis Haki Kolektif-Komunal, Malang: Setara Press.

Dwi Edi Wibowo, "Ewuh Pakewuh Cultural Reconstruction to Equal Consumer Protection", Jurnal Bestuur, Volume 8, No. 1 (2020).

Ganefi, Sinergitas Industri Kreatif Berbasis Hak Kekayaan Intelektual Dalam Menunjang Pariwisata, Supremasi Hukum : Jurnal Penelitian Hukum, Vol. 28, No. 2, Agustus 2019.

I Nyoman Lodra, Komodifikasi Makna Tenun Gringsing sebagai "Soft Power" Menghadapi Budaya Global, Jurnal Kajian Bali Volume o6, Nomor o1, April 2016

Indra Rahmatullah, "Pelindungan Indikasi Geografis Dalam Hak Kekayaan Intelektual (Hki) Melalui Ratifikasi Perjanjian Lisabon", Jurnal Cita Hukum, Vol. I No. 2 Desember 2014

Ok Saidin. 2004. Aspek Hukum Hak Kekayaan Intelektual, Jakarta: Raja Grafindo Persada.

Lego Karjoko, Zaidah Nur Rosidah, I Gusti Ayu Ketut Rahmi Handayani, "Refleksi Paradigma Ilmu Pengetahuan Bagi Pembangunan Hukum Pengadaan Tanah", Jurnal Bestuur, Volume 7, No. 1 (2019).

Lukman Hakim, Industri Pariwisata Dan Pembangunan Nasional, Among Makarti, Vol.3 No.5 Juli 2010

Martin Roestamy, "Model Land Supply for Land Bank to House Application", Jurnal Bestuur, Volume 8, No. 1 (2020). 
Najella Zubaidi, Regy Gusti Pratama, Sholahuddin Al-Fatih, "Legal Perspective on Effectiveness of Pre-Work Cards for Indonesian People”, Jurnal Bestuur, Volume 8, No. 1 (2020).

Nurfaika Ishak, Rahmad Ramadhan Hasibuan, Tri Suhendra Arbani, "Bureaucratic and Political Collaboration Towards a Good Governance System”, Jurnal Bestuur, Volume 8, No. 1 (2020).

Nizar Apriansyah, Perlindungan Indikasi Geografis Dalam Rangka Mendorong Perekonomian Daerah, Jurnal Penelitian Hukum De Jure, Vol. 18 No. 4, Desember 2018.

Arif Jumari, "Potensi Pelanggaran Pengelolaan Limbah Bahan Berbahaya dan Beracun”, Jurnal Bestuur, Volume 7, No. 2 (2019).

Abdul Kadir Jaelani, "Implementasi Daluarsa Gugatan Dalam Putusan Peradilan Tata Usaha Negara di Indonesia”, Pena Justisia: Media Komunikasi dan Kajian Hukum, Volume 18, Nomor 2 Tahun 2019.

Abdul Kadir Jaelani, Alexander A Kurniawan, Lusia Indrastuti "Pelaksanaan Standarisasi Pemberian Paten Dalam Invensi Bidang Obat-Obatan Di Indonesia”, Legality: Jurnal Ilmiah Hukum, Volume 27, Nomor 2 Tahun 2019

Ni Ketut Supasti Dharmawan, Dkk, Kepariwisataan Berbasis Budaya Kuliner Dalam Perspektif Hukum kekayaan Intlektual, Proseding APHKI, Lombok, 2017

Nurul Barizah, Masukan Indikasi Geografis Ruu Merek, Makalah Disampaikan Pada Rapat Dengar Pendapat Umum Ruu Tentang Merek, Jakarta, 16 Maret 2016.

Putri Diana, I Ketut Suwena, Ni Made Sofia Wijaya, Peran Dan Pengembangan Industri Kreatif Dalam Mendukung Pariwisata Di Desa Mas Dan Desa Peliatan, Ubud, Jurnal Analisis Pariwisata ISSN : 1410 - 3729, Vol. 17 No. 2, 2017

Rian Saputra, Adi Sulistiyono, Emmy Latifah, Pendaftaran Internasional Sebagai Upaya Perlindungan Indikasi Geografis Indonesia Dalam Perdagangan Global (Studi Peraturan Pemerintah Nomor 22 Tahun 2018), Jurnal IuS Kajian Hukum dan Keadilan Vol 7 Nomor 2 Agustus 2019 , Inventarisasi Potensi Indikasi Geografis Dalam Upaya Memperkuat Sistem Perlindungan Hukum Indikasi Geografis di Indonesia, Thesis, Fakultas Hukum, Universtias Sebelas Maret Surakarta, 2020.

Siti Asfiyah, Perlindungan Hukum Potensi Indikasi Geografis Di Kabupaten Brebes Guna Pengembangan Ekonomi Masyarakat Lokal, Jurnal Idea Hukum Vol. 1 No. 2 Edisi Oktober 2015,

Trias Palupi Kurnianingrum, Pelindungan Hak Ekonomi Atas Indikasi Geografis, Negara Hukum: Vol. 7, No. 1, Juni 2016

Tomi Suryo Utomo. 2009. Hak Kekayaan Intelektual (Hk) Di Era Globalisasi: Sebuah Kajian Kontemporer, Yogyakarta: Graha Ilmu.

Triwanto Triwanto, Esti Aryani, “The Urgency of Granting Authority to Assess Corruption Justice Collaborators", Jurnal Bestuur, Volume 8, No. 1 (2020). 